$11-17-2019$

\title{
Naming, Race, and White Supremacy in the Teaching of Religion and Islam: Incorporating Intersectional Interventions
}

Martin Nguyen

Follow this and additional works at: https://digitalcommons.fairfield.edu/religiousstudies-facultypubs

(C) 2019 John Wiley \& Sons Ltd

This is the peer reviewed version of the following article: "Naming, Race, and White Supremacy in the Teaching of Religion and Islam: Incorporating Intersectional Interventions," Teaching Theology and Religion, vol. 22 no. 4 (October 2019), 239-252, which has been published in final form at https://doi.org/10.1111/teth.12501. This article may be used for non-commercial purposes in accordance with Wiley Terms and Conditions for Use of Self-Archived Versions.

\section{Peer Reviewed}

\section{Published Citation}

"Naming, Race, and White Supremacy in the Teaching of Religion and Islam: Incorporating Intersectional Interventions," Teaching Theology and Religion, vol. 22 no. 4 (October 2019), 239-252. https://doi.org/10.1111/ teth. 12501

This item has been accepted for inclusion in DigitalCommons@Fairfield by an authorized administrator of DigitalCommons@Fairfield. It is brought to you by DigitalCommons@Fairfield with permission from the rightsholder(s) and is protected by copyright and/or related rights. You are free to use this item in any way that is permitted by the copyright and related rights legislation that applies to your use. For other uses, you need to obtain permission from the rights-holder(s) directly, unless additional rights are indicated by a Creative Commons license in the record and/or on the work itself. For more information, please contact digitalcommons@fairfield.edu. 


\title{
Naming, Race, and White Supremacy in the Teaching of Religion and Islam: Incorporating Intersectional Interventions
}

\begin{abstract}
The need to confront issues of race and white supremacy in our teaching of religion is critically important, but through the pedagogical convention of naming, we take the first step in inviting our students to understand the how's and why's of it. I will explore the ways that Charles Long's theory of signification and counter-signification can be pedagogically deployed to incorporate intersectional interventions in the teaching of religion in America, specifically in the case of an Islam in America course.
\end{abstract}

\section{Keywords}

Black Lives Matter, Signification, Race and Religion, White Supremacy, Racism, Naming, Islam and Race 


\section{Black Lives Matter}

\#BlackLivesMatter. Whether voiced aloud, inscribed onto signs and shirts, or reverberated across social media, \#BlackLivesMatter are words that seek witness in our present moment. They are words that need speaking. They are words that demand teaching. These words have emerged in our times because they name a widespread, persistent, and long-enduring racial crisis that we have continually failed to recognize and rectify, namely that black lives do not matter across our social, cultural, political, legal, or economic calculi. In the context of the classroom, the naming of \#BlackLivesMatter is important. Indeed, I use the naming of \#BlackLivesMatter - both inscribed and uttered and as a declaration and a point of interrogation - to frame how I go about teaching religion, specifically my course on Islam in America, in order to help students towards these learning outcomes: a) to understand the modern racial discourse across different historical, religious, and cultural contexts, b) to approach race and racism from an intersectional perspective, and c) to appreciate the significance and ethical complexities of \#BlackLivesMatter today. Those words, \#BlackLivesMatter, impel us to examine how we are confronting issues like white supremacy, racism, and colonialism in our teaching of religion, despite the pedagogical difficulties that such incorporations might entail. Although the act of naming is far from a sufficient salve against the enormity of structural racism - and can be complicit with it as I shall discuss below - it allows those in the classroom, both our students and ourselves, to begin to consider how that system can be productively unsettled and disrupted in our wider lives.

I admit that I could have and for a time did skirt issues of racial justice in the courses that I taught. The reasoning came easily enough. First of all, I did not have to do so. I had been hired to teach survey courses on Islam. With so much content to cover, how could I possibly take the 
time to substantively engage questions of race and racism as well? Secondly, could I do so competently? I did not feel prepared to undertake the task. My training was in textual interpretation and the history of pre-modern Muslim societies and not critical race theory or the racial dimensions of the fields in which I trained. Nevertheless, the convergence of contemporary currents - the emergence of the Black Lives Matter movement especially - and my exposure to the pedagogical scholarship about teaching race and racism compelled me to reconsider my earlier circumspection of teaching racial justice. Through the work of numerous preceding scholars, I came to realize that the classroom was precisely the place where I could address the social injustices that I witnessed and with which I was structurally complicit. (Tatum, 1992; hooks, 1994; DiAngelo, 2011; Pliner \& Banks, 2012; Case, 2013; Yancy \& Davidson, 2014; Mitchell, 2018). Moreover, the ongoing social realities of racial injustices drove home the urgency of the matter. I realized that I could not wait for a sufficient sense of preparedness. Rather, I needed to undertake this learning experience alongside my students and to share with them the vulnerability and difficult conversations that the endeavor would entail. With these concerns in mind, I intentionally changed how I went about teaching my religious studies courses. The transition, of course, was not always easy. One way I was able to enact this change was to rebuild one of my courses thematically around \#BlackLivesMatter, rather than merely adding it onto an already set syllabus. While work certainly remains with respect to content and expertise, my usage of naming helped to pivot the course along a more ethically attentive trajectory.

I identify in the act of naming, which \#BlackLivesMatter exemplifies, an important and accessible device for pedagogical intervention. While it is all too easy to overlook, obfuscate, or circumvent discussions of race and white supremacy in the teaching of religion, the act of 
naming helps to center such a turn. I argue that a sustained engagement with naming offers students multiple opportunities to better understand how religion relates to the systemic nature of racism and intersectional identities. As a scholar of religious studies, I had wanted students to appreciate how religion figures into the epistemic, social, and political matrices of human societies. Now I wanted them to appreciate as well how religion figures into the epistemic, social, and political matrices of white supremacy. The act of naming, as a form of "countersignification," can be used to structure a course in such a way to efficaciously shape, redirect, or pivot the trajectory of a course towards under-examined intersections.

I am using the term "counter-signification" as formulated by two scholars of African American religions, Charles H. Long, whose work more broadly concerns the history of religions, and Richard Brent Turner, whose research concerns African American Muslims. For Long (1986), "signification" marks the ways by which a dominant group subjugates, denigrates, and/or marginalizes another group, while "counter-signification" represents the ways by which the non-dominant group works to resist and subvert that power dynamic (pp. 1-2). Building on Long's work, Richard Brent Turner (2003) uses counter-signification as the primary analytical lens in Islam in the African-American Experience, one of the main books that I assign in my Islam in America course. I wanted to operationalize Long's disciplinary theory of signification and counter-signification for the teaching of religious studies, and not just the study and analysis of it.

For the purposes of the present article, the case study is my Islam in America course. Nonetheless, the technique of naming and the pedagogical structure that it provides could easily be used to address race and white supremacy for courses focusing on other religious traditions and identities. What I share herein are the class discussions and activities that I facilitate over the 
first few weeks of the term and then an overview of how the remainder of the course continues with the \#BlackLivesMatter theme and "counter-signification" as the mode of inquiry. By the end of the article, I will explore how this case studied might be expanded or adapted in different ways. A caveat is also in order. While I will argue the act of naming is a useful device for reorienting a course towards matters of racial justice, it is far from a comprehensive solution. I hope rather to continue to develop my course in include other interventional and immersive elements like service learning, site visits, and other forms of community engagement.

\section{Naming as an Opening Activity}

At the very outset of my Islam in America course, I intentionally foreground the statement and movement of \#BlackLivesMatters as a defining frame of analysis. I do so for practical and pedagogical reasons. On the practical level, I want to connect the lived context of the students with \#BlackLivesMatters and what it signifies. I teach at Fairfield University, a Jesuit institution, where the mission of the university, like others like it, is driven by "a common commitment to truth and justice." I understand this to imply a commitment to liberatory praxis for sake of human dignity. I believe that addressing the ongoing struggles of racial justice in the United States and beyond helps to bring the university's mission to life for my students. While they are exposed to the mission of the university on an abstract level throughout their orientation, when they enter the classroom I want to ground that mission more concretely in America's ongoing racial discourse. On the pedagogical level, \#BlackLivesMatter literally opens my course because these words are written across the board on the first day. The inscription of \#BlackLivesMatter sets the tone for the rest of the term. Students become immediately aware that difficult discussions concerning race will direct the class, even if the subject of the course is 
Islam in America. The presentation of the phrase also serves as an accessible, if not instantly recognizable, form of naming. Whatever their understanding of \#BlackLivesMatter, students have encountered these words before entering the classroom. By opening with the phrase, I am signaling to them that we will explore and unpack its meaning together over the course of the semester.

Immediately following the phrase's inscription on the board, students are given the opportunity to free write their responses to a set of specific questions that I pose to them: When, where, and how do these words occur? What do these words mean to those who speak them? What do these words mean to the many who hear them? The precise wording is important because of the distancing that the phrasing creates. I want students to be able to share the full range of views that they are encountering in the public discourse, including populist and oppositional views as well as personal ones and those held by family and friends. Rather than sublimating certain opinions, my aim is to critically engage whatever emerges. Then, after the students share in pairs or small groups, the entire class comes together to record on the board the numerous possible responses.

The exercise has a number of objectives. On one level it serves to establish the history, context, and social reality behind these words. Although \#BlackLivesMatter may have gained prominence across social media and activist spaces in 2013 in protest of the acquittal of George Zimmerman in the murder of Trayvon Martin, the phrase continues to be signified today in public discourse (Taylor, 2016, pp. 150-151; Lebron, 2017, p. xi). \#BlackLivesMatter remains profoundly resonant for those who signify them. Additionally, opening with \#BlackLivesMatter reveals to students the power that lies behind naming as an act. In fact, naming does important work on multiple fronts. To name something like \#BlackLivesMatter is to give it life, to secure 
its place in social memory, and to draw attention to the broader underlying conditions that require addressing. Furthermore, it acknowledges the agency of the one doing the naming, whether it is an individual or a community. In the classroom, that can be empowering for students because it transforms the ongoing learning into a moment of resistance or as a restorative measure. It grants them agency in the classroom. Indeed, the fact that naming operates at multiple registers and means different things to those who employ is something that helps students to appreciate the ethical complexities that the course works to engage.

Naming is a meaningful action, but that meaningfulness varies with context, community, and person. In the case of \#BlackLivesMatter, the phrase spotlights specific moments of trauma and tragedy in the murder of black men and women. It also names a recurring call to action, the need to gather, mobilize, and affect radical change. It names a movement, the trans-historical struggle with which innumerable men and women are continually engaged. It names racial injustices pandemic to the country, namely police brutality and the new Jim Crow. It names America's pervasive culture of white supremacy, white privilege, institutional racism, and what philosopher Charles W. Mills (1997) identifies as the racial contract that underlies it. \#BlackLivesMatter, then, names at once these many different things and more.

These various registers of meaning and significance, however, requires extensive reflection and guided discussion. The students and I need time to examine and reflect on how our individual identities relate to the social complexes that we are engaging. As education specialist Tania Mitchell underscores, a focus on identity can critically aid learners in shifting their focus from the individual to the systemic (2015; Mitchell et. al., 2015). I am careful, then, to take the time to draw out each point that emerges from the class-wide discussion. A continual return to the initial set of three questions that I raised allows the class to consider the naming of 
\#BlackLivesMatter from numerous perspectives. As a result, I set aside our entire first class together to explore as fully as possible the activity, while recognizing that we will have to revisit these questions periodically throughout the course as we continue our conversation and encounter new readings and issues. Part of Mills' The Racial Contract (1997), for example, is assigned the following week to better anchor, with regards to theory, our opening activity.

Additionally, I make it a point to emphasize on the first day that as central as \#BlackLivesMatter may be to my Islam in America course the act of naming extends beyond the specificities of the named phrase. Rather, \#BlackLivesMatter is part of a broader phenomenon of ethically driven naming that the course will trace and explore in future weeks. This opening activity is intended to signal to my students that naming will recur throughout the course as a means of inquiry. By foregrounding the convention of naming as a means of critical inquiry, it establishes a habit of expectation that each future name presented to the class will lead the class to new perspectives to consider or down new avenues of investigation. Indeed, it is precisely through continued reflection on a series of new names that the intersection of race and religion is explored.

Finally, the opening discussion of \#BlackLivesMatter allows space for oppositional forms of naming to be raised and analyzed. Counter-phrases like "all lives matter" or "blue lives matter" are regularly elicited. These "shadow texts," as philosopher Alison Bailey aptly characterizes them, should not be dismissed, but engaged with equal scrutiny in order to "direct... attention to the ways epistemic resistance circulates during classroom discussions" (Yancy, 2017, p. 69). Thus, whenever shadow texts are raised, we interrogate them in the same way as \#BlackLivesMatter. When, where, and how do these words occur? What do these words mean to those who speak them? What do these words mean to the many who hear them? While 
shadow texts may appear well intentioned superficially, sustained questioning reveals that they are framed in distinction to, if not opposition to \#BlackLivesMatter. Deployed defensively, phrases like "all lives matter" work to subvert the conversation away from race and white supremacy altogether. In fact, they appear exclusively in response to a text, hence "shadowing" it. Maneuvers such as this exemplify Long's (1986) understanding of signification, in contrast to counter-signification:

Signifying... obscures and obfuscates a discourse without taking responsibility for so doing... the signifier may speak in agreement with a point of view, while the tone of the voice creates doubt in the very act and words of agreement. Or the signifier may simply add comments that move the conversation in another direction. Or the signifier will simply say a word or make a comment that has nothing to do with the context of the discourse, but immediately the conversation must be formulated at another level because of that word or phrase. (p. 1)

While it is too ambitious to exhaustively critique these oppositional counter-phrases on this first day of class, a side-by-side interrogation helps to reveal, at the very least, how naming always transpires in contexts of privilege and power. Students are made aware that shadow texts like "all lives matter" - an example of signification - work to silence, obfuscate, or redirect attention away from the original call to racial justice at the heart of words like \#BlackLivesMatter - an example of counter-signification. They learn that not all naming is equal.

\section{Race, Religion, and the War of Words}

A growing body of scholarship has pointed to the intersection of race and religion in America. The work of Ann Burlein (2002), Willie Jennings (2011), Kelly Baker (2011), and 
Jeaninne Fletcher (2017), among others, has critically delineated the historical and genetic connections between white supremacy and Christianity. While the issue may seem at a remove for a course on Islam in America, I believe it important for students to understand how Christonormativity figures into the American context within and against which Islam and Muslims are being studied. Rather than diving deeply into texts, however, I spend the second week engaging with three interrelated names that gradually reveals this historical and ongoing reality: the War on Crime, the War on Drugs, and the War on Terror.

Even though appearing decades earlier, these three names can be imagined as the converse of \#BlackLivesMatter. Whereas the counter-signification \#BlackLivesMatter emerged from out of grassroots activist spaces, these so-called wars were signified by the state. To prepare my students for this conversation, they are asked to watch $13^{\text {th }}$, Ava DuVernay's 2016 documentary about race and mass incarceration in the United States, because of the film's explicit exploration of the War on Crime and the War on Drugs. Then, I ask students, based on their understanding of the film, to unpack the origins and supposed parameters of each so-called war and to describe their commonalities and differences. We discuss how the War on Crime, first declared by Richard Nixon, gained traction throughout the late 1970s and early 1980s. Then, we interrogate the appropriateness of the war metaphor. On the one hand, the War on Crime differs from conventional armed conflicts. It is amorphous; the enemy is ultimately the phenomenon of crime itself, rather than persons or a nation state. Impossibly, crime must somehow end in order to conclude this war. On the other hand, like a conventional war, there are frontlines - America's inner cities, soldiers - an increasingly militarized police, wartime industry - the private prison industrial complex, and wartime legislation to orchestrate it all - like mandatory minimum 
sentencing and the three-strikes law. Most importantly, of course, there is an enemy to dehumanize: black men, women, and children are rebranded as criminals.

Then, the War on Drugs becomes a case for how the state-sponsored model of amorphous war was expanded to other fronts. Historically, the American War on Crime followed quickly on the heels of the War on Crime. A drug tsar was appointed to command forces and achieve victory. Whereas the war on crime was squarely focused on the domestic front, namely black neighborhoods and deteriorating city centers, the war of drugs introduced an international front sweeping LatinX communities into the combatant other. Brown lives were and continue to be rebranded as drug runners and illegal immigrants. With both these wars black and brown lives came under threat politically, economically, socially, and culturally.

I draw attention to these first two so-called wars, in which Muslims do not seem involved, in order to connect it to the latest named amorphous war where race and religion most explicitly intersect: the War on Terror, inaugurated in the immediate aftermath of the terrorist attacks on September 11, 2001. It shares many of the features of its predecessors in that this war has both domestic and international fronts. And like the previous amorphous wars, it was publically named to justify state-sponsored surveillance, discrimination, and violence. Where it differs is the ways that religion explicitly figures into the rhetoric of war. At this point in the class, we pause to closely read contemporary texts. The class traces how Muslim religious identity came to be racialized, or rather further racialized, by analyzing the political rhetoric of presidential speeches, government documents, and everyday news reporting. We track how Muslims are dehumanized through the idea of terrorism, study the religious reductionism underlying particular images and symbols, like the headscarf and prayer, and question the motives driving the political rhetoric of crusades, jihad, security, and normalcy. By reading such 
texts together, students are better able to appreciate the congruencies between these amorphous wars on crime, drugs, and terror, can more clearly identify connections between the historical experiences of black, brown, and Muslim communities in the United States, and are better able to delineate the volatile power differentials at work between the white supremacist institutional mainstream and the grassroots efforts of minoritized groups. Furthermore, through this series of engagements with amorphous wars, students are also exposed, sometimes for the first time, to the Christo-normativity underlying the War on Terror, a subject that becomes more central as the course proceeds.

Additionally, the second week serves to demonstrate the substantially different ways that language can be deployed. Whereas \#BlackLivesMatter is rooted in a discourse that affirms the value and dignity of black life and the need for radical change, the negative rhetoric of amorphous war depends upon a discourse of fear, anxiety, security, and dehumanization aimed at preserving a white supremacist status quo. Crime, drugs, and terror, respectively associated with those who are black, brown, and Muslim, must be held at bay from the everyday tranquility of law-abiding, white Christian citizens. Overall, the exercise helps to sharpen for my students the contrasting ways that signification - the top-down rhetoric of amorphous war - and countersignification - the bottom up movement of \#BlackLivesmatter - unfold and move against one another.

The exploration of \#BlackLivesMatter and then the three interrelated amorphous wars help set the stage of inquiry for the remainder of the term. Both engagements signal to students the abiding currency of these conversations on race, racialization, and white supremacy. Nonetheless, these same names do not necessarily direct students back to the history of America, which serves as the structural backbone of my Islam in America course. There is a longer history 
of social justice and naming that I want my students to appreciate and understand with respect to race, white supremacy, and Islam in America. As a class, we must move back past the late 1970s. It is at this point in the class that I want to reorient my students towards more in-depth sustained investigations of subjects like American slavery and the Nation of Islam. To that end, the third introductory week for my Islam in America course is centered on three distinctive sets of names.

\section{Naming Beyond \#BlackLivesMatter}

For the third week, I write the following names on the board and ask students to relay what they know of about any of these names:

Michael Brown

Eric Garner

Tamir Rice

Freddie Grey

Sandra Bland

Philando Castile

Terence Crutcher

Charleena Lyles

Stephon Clark

I selected these names because, like \#BlackLivesMatter, they all have been publicly countersignified out in the world. Communities raised each of these names in outrage and protest of the systemic white supremacy that murdered these black lives. While I usually discourage electronic devices in the classroom, I inform students that for the duration of this activity they can make use of them in order to better understand the lives and deaths represented here. We document each 
name, moving systematically down the list and forward in time towards the present moment. ${ }^{1}$ In a short time, most students are able to recognize a pattern. Even if they were unfamiliar with the circumstances behind each name prior to the day's activity, they are able to quickly anticipate the tragic narrative that brings these names together in a short time. Although several sessions could be set aside to carefully study each name, my aim here is for my students to better understand how the naming of \#BlackLivesMatter in 2013 was never meant to stand only for the death of Trayvon Martin, but continues to name each life that has been wrongly taken since then.

Each name renders legible the invisible workings of white supremacy. These particular names raise questions as to the lives taken as well as the circumstances, powers, and people that took them. What made these fatal converges possible? More pointedly, what allows for the regularity of these fatalities? By naming these deaths together it prompts students to look at the larger institutional problematic being signified. The set of issues under investigation is no longer pinned to the specificities of Michael Brown, Tamir Rice, or Charleena Lyles, but to the array of social, cultural, economic, legal, and political forces that make these deaths possible, excusable,

\footnotetext{
${ }^{1}$ Michael Brown, 18 years old, was fatally shot by Ferguson police officer Darren Wilson on August 9, 2014; Wilson was not charged. Eric Garner, 43 years old, was was choked to death by New York City police officer Daniel Pantaleo on July 17, 2014; a grand jury decided not to indict Pantaleo. Tamir Rice, 12 years old, was shot by on November 22, 2014 by Cleveland police officer Timothy Loehmann and died of his wounds the next day; a grand jury decided not to indict Loehmann. Freddie Carlos Gray, Jr., 25 years old, died under Baltimore police custody on April 19, 2015 after his spinal cord was severely injured during his arrest five days earlier and never receiving any medical treatment; the six police officers involved were either acquitted or had the charges against them dropped or not pursued. Sandra Bland, 28 years old, was found hanged in her jail cell on July 13, 2015 after having been arrested by the Waller County, Texas sheriff's department during a traffic stop three days earlier. Philando Castile, 32 years old, was fatally shot by St. Anthony, Minnesota police officer Jeronimo Yanez during a traffic stop on July 6, 2016; a jury acquitted Yanez of all charges. Terence Crutcher, 40 years old, was fatally shot by Tulsa police officer Betty Jo Shelby on September 16, 2016; a jury found Shelby not guilty. Charleena Lyles, 30 years old, was fatally shot by Seattle police officers Steven McNew and Jason Anderson on June 18, 2017. Stephon Clark, 22 years old, was fatally shot by two Sacramento police officers on March 18, 2018.
} 
tolerable, and recurring. In other words, radiating out from each name are concentric circles of crises. While each name memorializes a life lost to police brutality, each name also reveals the institutional racism that runs through the criminal justice system, indicts a culture that criminalizes blackness, and discloses what Mills (1997) describes as "the racial contract" that has been at work to sustain white supremacy within society. Also important is that these lives have been explicitly named by racial justice activists in the same grass roots manner as \#BlackLivesMatter. They represent the ongoing resistive power of counter-signification or the ability for a non-dominant community to name themselves.

The second set of names that I then write on the board serves to broaden the historical horizon of investigation. I write the following names on the board in this specific order:

Ramarley Graham

Danroy Thomas Henry Jr.

Aiyana Jones

Oscar Grant III

Sean Bell

Timothy Stansbury Jr.

Amadou Diallo

For the sake of time, I provide the details for each name myself. ${ }^{2}$ I emphasize the date of each death, which starts in 2012 and ends in 1999, so that my students recognize that they are now

\footnotetext{
${ }^{2}$ Ramarley Graham was slain by police in his New York apartment on February 2, 2012. Danroy Thomas Henry Jr. was shot and slain by police in New York City on October 17, 2010. Sevenyear-old Aiyana Jones was killed in a police raid in Detroit on May 16, 2010. Oscar Grant III was shot and killed by police in Oakland on January 1, 2009. On the morning of his wedding, Sean Bell was shot and killed by plainclothes undercover police officers in New York on November 25, 2006. Timothy Stansbury Jr. was slain by police in New York City on January 4,
} 
being directed progressively further back in time. When taken altogether, these names trace out a longer historical arc that predates \#BlackLivesMatter. As Lebron (2017) has done in his book on the movement, I want students to see that \#BlackLivesMatter not only names an ongoing crisis, but names a long enduring one that predates it.

This relatively brief enumeration of names in the second set serves to better contextualizes the third set of names that I then write alongside the first two:

Fred Hampton

Martin Luther King, Jr.

Jimmie Lee Jackson

Malcolm X

Addie Mae Collins

Denise McNair

Carole Robertson

Cynthia Wesley

Medgar Evers

Emmett Till

Given the greater prominence that these particular names have earned in mainstream American history, I have my students once more take on the responsibility of detailing the significance of each named person. Who is the person named? How did they die? How did they live? I ensure that the most basic details of each death are documented in a way that parallels the earlier set. ${ }^{3}$

2004. Amadou Diallo, an immigrant from Guinea, was shot and killed by four plainclothes police officers in New York City on February 4, 1999.

${ }^{3}$ On December 4, 1969, Fred Hampton, a rising voice of leadership in the Black Panther Party, was slain in Chicago during a raid organized by local, state, and federal law enforcement agencies. On April 4, 1968 the outspoken civil rights leader Dr. Martin Luther King, Jr. was 
Like before, students are transported even further back in time recognizing that these names also represent black lives slain upon a horizon of white supremacy.

The names that could be signified in the classroom are endless. The list is never complete. The record is ongoing, stretching back into the haze of undocumented pasts and continuing for the foreseeable future. Because of this overabundance of tragedy, the names used for the first set ought to be updated regularly. Many other names could be included in the latter two sets of names as well, some of which are known, some of which are waiting to be discovered and remembered, and some which will never be historically recovered.

After covering the basic details of the third set of names and identifying the historical era as that of the Civil Rights struggle, the focus of the class then narrows onto the religious. I ask students, where do they see religion figuring amongst these names? The conversation often moves to the most obvious points of intersection. Klansmen killed the four young girls, Addie Mae Collins, Denise McNair, Carole Robertson, and Cynthia Wesley, in their firebombing of a Baptist church in Birmingham, Alabama. The tragic incident provides an opportunity to discuss the complexities of Christianity in the American South. On the one hand, much of the Civil Rights activism of the era was animated by a Christian ethical vision of justice, as demonstrated by Dr. King, a Baptist minister, and Jimmie Lee Jackson, a Baptist deacon. On the other hand, the Ku Klux Klan claimed a Protestant Christian foundation, while the burgeoning white

assassinated. The Selma marches of 1965 drew upon the outrage and activist energy that emerged after civil rights activist Jimmie Lee Jackson was fatally shot by Alabama State Troopers on February 26, 1965. Human rights activist Malcolm X was assassinated on February 21, 1965. On September 15, 196311 year old Denise McNair and 14 year old Addie Mae Collins, Carole Robertson, and Cynthia Wesley lost their lives in the $16^{\text {th }}$ Street Baptist Church in Birmingham, Alabama when it was firebombed by white men affiliated with the Ku Klux Klan. On June 12, 1963 civil rights activist Medgar Evers was assassinated by a Klansman. On August 28, 1955 Emmett Till, 14 years old, was lynched by two white men who were later acquitted of the crime. 
evangelical fundamentalist movement remained ambivalent, if not supportive of racial segregation (Baker 2011; Burlein, 2002; Johnson, 2015; Schulman, 2012). At this moment, I typically point out how the ambivalence of Christian evangelical fundamentalists operated as a shadow text to the efforts of Dr. King and the Southern Christian Leadership Conference, much like how "all lives matters" is invoked in response to \#BlackLivesMatter.

I use the discussion of Christian complicity with white supremacy as a means of introducing the concept of intersectionality into the course. According to theories of intersectionality, racism, as a form of prejudice, never operates alone (Johnson et al., 2012). The construct of race is deeply interconnected to other social categories, like class and gender, within matrices of domination. The same persons named above could also be productively examined from an intersectional perspective. For example, Dr. King, in the months prior to his assassination, helped to organize the multiracial Poor People's Campaign, cognizant of the interrelatedness of economic justice to racial justice. Similarly, in his final year of life, Malcolm $\mathrm{X}$ turned to the international community for support recognizing the strikingly similar structures of power at work in American segregation and European colonialism. The specific connections that are made can vary with each iteration of the course. What is pedagogically important here is the ability of naming to thematically thread together specific persons, events, or phenomena, which in this case is the intersection of religion and race.

In the teaching of Islam in America, I use intersectionality to explore how religion and religious identity figure, or do not figure, into discourses on race and white supremacy. As with the case of Birmingham firebombing, students can see Christianity at work on both sides, which serves to underscore how Christo-normativity pervades the American context. Indeed, one need not identify as Christian in order to benefit from Christian privilege. As Accapadi (2009) acutely 
notes “...Christianity, and emulation of physical representations of Christianity, religious or secular, itself offers access and entry to mainstream societal norms in a way that no other religious identity can ever rival in the United States" (p. 123). Teaching at a Jesuit university, I believe it especially important for my students to appreciate this point since Christian privilege sets the parameters of how we talk about faith, religion, and secularity in the classroom and across campus.

At this point in the class discussion, I direct attention to the case of Malcolm X to better understand how the intersection of race and religion need not be confined to Christo-normative expectations. For much of his public career, Malcolm X was a prominent minister in the Nation of Islam, which was explicitly counter-signified by its adherents as a more authentic AfricanAmerican religion than Christianity. Whereas Christianity was framed as an inheritance imposed by white slave masters, the Nation of Islam was presented as fundamentally and genealogically black in nature and orientation. Then, when Malcolm X left the Islam of the Nation, he turned to Sunni Islam, which he envisioned as a global tradition unburdened by the domestic racial complex of America. At this point, the course can be directed to pursue a number of trajectories, such as further investigating the Cold War intersections of race and religion, tracing out the history of the Nation of Islam, or analyzing the religious dimensions of Malcolm X's life and legacy. While naming helps to direct my religious studies course towards issues of race and white supremacy, it does not confine it towards specific routes or paths of inquiry. Rather, I can use naming to explore a variety of directions and questions.

\section{Naming Islam Against Christo-normativity}


The key development by the fourth week of the semester is twofold. First, naming has helped to establish race and white supremacy as a defining theme of critical inquiry for this course on Islam in America. Second, the convention of naming has become a familiar enough pedagogical device for the students that I can continue to use it periodically through the remainder of the course whenever suitable. With these structural expectations in place, Turner's work helps to turn the course more explicitly to the history of counter-signification and Islam in American religious history. Turner (2003) writes:

...the issue of naming is crucial to the formation of black identity in North America. Unlike white Americans, African Americans, who were involuntarily taken away from their land of origin, have been stripped of their genealogy and their history. For these Americans to reclaim a cultural identity, they must not only reject the names imposed upon them by their former slave masters or chosen from a European repertoire, but also create new names that signify new identities. Since the colonial era, Islam has provided black Americans with alternative names and identities (p. 1).

The Islam in America course, then, can be designed along a number of thematic and historical axes. In this section and the next, I share two teaching modules that capitalize on the priming of my students to the naming of race and white supremacy for the teaching of Islam in America. Malcolm X, of course, is not the only black figure who formed his religious identity outside or against the Christian norm.

Noble Drew Ali

Daoud Ahmed Faisal

Wallace Fard Muhammad

Elijah Muhammad 


\section{El Hajj Malik El Shabazz}

Warith Deen Mohammed

Louis Farrakhan

The lives signified above, which scholars like Turner (2003), Aminah McCloud (1995), Edward Curtis (2002), and Robert Dannin (2002) have covered, broaden the class's engagement with religious privilege by naming Islam as a symbolic, religious, and social identity aimed at disrupting Christo-normativity and white supremacy in America. Each person named here, from the earliest to the most recent, embodied Muslim-ness as an alternative, if not subversive, religious identity to Christian supremacy.

The first three names on the list represent men who developed counter-traditions to Christianity that were positively rooted in the otherness of Islam in America. Noble Drew Ali (d. 1929), born Timothy Drew, drew upon the constellation of Islam in formulating the new religious movement the Moorish Science Temple, which offered to its adherents an alternative racial identity to assume. The foreignness of being a Moor, Moslem, or Asiatic was provided as an alternative to being Colored, Negro, or African. Beginning in 1924, Daoud Ahmed Faisal (d. 1980), originally from Trinidad, worked to spread Sunni Islam amongst African Americans, especially in New York City. Rooted in anti-colonialism and Islamic revivalism, the Muslim identity that he fostered transformed black converts and connected them a wider Muslim world beyond the racially defined confines of America (Dannin, 2002, p. 63). In 1930, Wallace Fard Muhammad founded the Lost-Found Nation of Islam amongst the predominantly Baptist African-American population in Detroit and then Chicago. While his religious movement also drew upon Islam's symbolic universe, much like Noble Drew Ali's Moorish Science Temple, it 
also drew heavily and explicitly upon the Christo-normative lexicon with which his new adherents were already familiar.

The remaining four names represent men in successive generations who carried on and further developed the legacy of their predecessors. After Wallace Fard Muhammad's disappearance in 1934, Elijah Muhammad (d. 1975) would continue to lead the Nation as a counter-cultural religious community that defined itself through an array of countersignifications that included names, dress, habits, and social structures. His son, Warith Deen Mohammed (d. 2008), would transform that community further by leading most of its practitioners in a mass conversion to Sunni Islam during the late 1970s. Louis Farrakhan, for his part, would resurrect the Nation of Islam in 1978 largely readopting the set of countersignifications originally espoused by Wallace Fard Muhammad and Elijah Muhammad.

Malcolm X is included in the above list as well, but under the Muslim name he publicly assumed after completing the Hajj pilgrimage in April 1964, El Hajj Malik El Shabazz. As Manning Marable has pointed out in his 2011 biography of Malcolm X, Malcolm's own life is replete with a host of names revealing different dimensions of his life: "Malcolm Little, Homeboy, Jack Carlton, Detroit Red, Big Red, Satan, Malachi Shabazz, Malik Shabazz, El-Hajj Malik El-Shabazz" (p. 10). Each of these names, when signified and explored, offers a window into the broader African American experience of Islam and underscores the ways that marginalization, subjugation, resistance, and empowerment were imposed or made manifest.

\section{Naming Islam at the Beginnings of America}

Finally, as Turner has demonstrated, the naming of Islam can extend as far back as the beginnings of European settler colonialism in the Americas. 
Job ben Solomon

Yarrow Mamout

Abd al-Rahman Ibrahima

Bilali Muhammad

Lamine Kaba

Omar b. Said

Mahommah Gardo Baquaqua

Nicholas Said

These were the names by which these enslaved black men were known in the Americas. The early historical intersections of religion, race, and white supremacy can also be explored through their lives, which span the $18^{\text {th }}$ and $19^{\text {th }}$ centuries. Islam plays a central role in all of their narratives and nearly all of them were enslaved through the trans-Atlantic slave trade, with the exception of Nicholas Said who was sold into slavery to an Arab-African and arrived in the United States as a free man (Said, 2011; al-Ahari, 2006; Said, 2000). A number of these men gained recognition during their enslavement because of the religious learning that they possessed. Their education and Islamic faith, which was perceived to be closer to Christianity than other religious traditions held by enslaved Africans, made them appealing examples for the abolitionist cause. As a result, they were able to share some aspects of their narrative with the wider public. However, these specific lives are framed or arrayed in the course, their biographies and written narratives provide ample opportunity for the students to carefully unpack the privileges and challenges that each of their intersectional identities bore, especially the religious dimensions therein. 
Taken collectively, the naming here also challenges the dominant discourse with respect to history and mythic origins. More than a story of white men, the beginnings of the colonization of the Americas was also intimately bound up with black and Muslim lives. Rather than a latecomer to the story, Islam was present at the colonial start as a subjugated and sometimes subversive counterpart to white Christianity. The act of naming not only helps to direct discussion, but can also precipitate a category reconfiguration as students are prompted to rethink prevailing narratives.

Also warranting special attention is the fact that those named here were afforded the opportunity to tell their stories at all, whereas millions of others were denied this privilege. There is much that both signifying and counter-signifying omit and time can be taken in the classroom to explore these gaps, omissions, and obfuscations. For example, the named in this section are all male. What does this say about the un-signified experience of women? In what ways did these named voices challenge or were complicit in patriarchy, while working against white supremacy? How do class, ability, sexual orientation, or other identity categories intersect with religious identity in America? What else is being missed through the naming of individuals?

\section{Adaptive Trajectories}

The modularity of the course reflects my continual effort to refine, revise, and adapt my Islam in America course to the ever-evolving contemporary racial and Islamophobic discourses unfolding both nationally and internationally. There have been semesters when sections on history must give way to discussions of present day policy debates and legislation or units on refugees give way to discussions of recent hate crimes and vice versa. Additionally, I regularly have to update the counter-signifiers I name in the classroom for the sake of relevance and 
familiarity. When I teach this course next, for example, many of my students will be able to more quickly respond to the naming of Stephon Clark or Antwon Rose, Jr. than Michael Brown or Trayvon Martin. As time passes and living memories become points in history, the naming must adapt in order to first engage students at their entry points of familiarity before directing them down more historical and overlooked avenues of inquiry.

My continual rethinking and refining of the structure and direction of the course, however is also driven by shortfalls in learning. Even though I have found naming to be effective in setting the course trajectory across the various iterations, the learning outcomes do not always land as squarely as I would like for my students. Ultimately, I want my students to leave the course more literate in the religious and racial discourses of the United States. For me the measure of success is pinned to my students' ability, by term's end, to identify and explain for themselves specific kinds of significations and counter-significations: first, with respect to race and white supremacy, and second with respect to race and religion. Initially, I asked these questions through in-class exam essay questions, but realized that students needed more time to carefully unpack what they identified. The subject, after all, is nuanced and complex. When I turned to short papers, students were more readily able to research and critically uncover these intersections at their own pace.

In their written responses, most students could identify acts of naming akin to \#BlackLivesMatter. They frequently mentioned counter-significations like "Black Power," "Black is Beautiful," "Hands Up, Don't Shoot," and "I Can't Breath.” Fewer of those students could go further to identify counter-significations that were sartorial or embodied in nature. Those that did where able to note things like the distinctive attire of the Black Panthers, the black power salute, or NFL quarterback Colin Kapaernick's kneeling at the performance of the 
national anthem prior to football games. These students were able to see counter-significations as more than just words or things literally named.

Where I had the most mixed results, however, was with respect to significations used by the discourses of oppressive power and the religious dimensions overall. First, their answers tended more to the historical, rather than the contemporaneous. For instance, the early Klu Klux Klan and Nation of Islam typically received more attention than more recent examples. Students tended to default to the safety of historical distance. Second, when students did mention more contemporaneous examples, they gravitated to cases of resistance rather than complicity and oppression. Although we spent time as a class critiquing Christo-normativity and Christian supremacy, students demonstrated greater reticence in surfacing how these phenomena are still at work today in perpetuating racism and white supremacy. This, I believe, is due in large part to personal comfort and familiarity. Understandably, issues of complicity are more difficult to discuss if aspects of one's identity are implicated or brought into question. As DiAngelo (2011) has discussed, white fragility is a pervasive pedagogical barrier, especially for a course that is not ostensibly about race, but religion. Unfortunately, I do not believe there are any shortcuts in working through the issue.

Furthermore, there is the problem of time. All too often, I feel like more time could have been spent unpacking the significations and supremacies against which the course's countersignifications are leveled. In fact, the written responses of my students demonstrate that they can sense or spot the structural problems and issues, but then they have difficulty in parsing these out. In response, I continue to work to find the right balance of time and exposure to relevant reading materials, discussion topics, and in-class exercises that provides them with the knowledge, skills, and confidence to analyze the intersections of religion and race. Ultimately, 
the changes I make tend more towards quality over quantity. While I may not be able to cover as much history and material as in previous iterations of the course, I am finding that taking the time to fully explore a few choice modules better prepares my students in the long run. The closer engagement with a smaller subset of cases and content units appears to give the class greater facility with the concepts and analytical skills overall. If I cannot and should not cover it all, I am constantly asking myself what material will work most effectively with the weeks that we have together?

In sum, I use signification and especially counter-signification to introduce how blackness and Muslim-ness have intersected in a number of significant ways from the enduring place of Islam in the African American imagination to the racialization of Muslims in America to the long historical experience of African American Muslims that includes groups like the Moorish Science Temple and the Nation of Islam and persons like Elijah Muhammad, Malcolm X, and Muhammad Ali. While the case study for this article was Islam in America, the technique of naming and the pedagogical structure that it provides could easily be used with other religious traditions and identities for teaching about race and white supremacy. Islam, I argue, has no exclusive hold or advantage in revealing the intersections of religion with race and white supremacy. Other religious traditions can be critically explored through signification and counter-signification just as fruitfully as well. Throughout the preceding treatment, for example, I have also been identifying or alluding to Christian elements that challenge the Christonormativity underlying white supremacy. Some of these lives I have named explicitly, like Martin Luther King, Jr. and Jimmie Lee Jackson. Others can be advantageously surfaced by strategically naming them during the course of a term, whether they were part of early abolitionist efforts, the Social Gospel movement, the Southern Christian Leadership Conference, 
or some other counter-signifying person, group, movement, or community. The naming of \#BlackLivesMatter could also be set alongside historical efforts to combat anti-Semitism and anti-Catholicism in the United States if framed along the lines of religious identity or alongside other forms of racism if framed along other ethnic identities, as with LatinX or Asian-American communities.

Finally, the device of naming need not be restricted to shining a light on the intersection of religion and race alone. In fact, \#BlackLivesMatter does not have to serve as the exemplary, heuristic case. A religious studies course could be structured around the naming of \#MeToo to critically explore how religion intersects with gender, patriarchy, and misogyny or \#SayHerName could be named in order to more explicitly interrogate the intersections of race, gender, and religion against the persistent structures of supremacy. However one chooses to structure their course vis-à-vis naming, I believe Long and Turner's formative theoretical work can be effectively deployed as a pedagogical strategy as well. Naming is more than providing students a list of terms. Terms represent for students what the instructor believes to be significant for the course. Its purpose is to be incorporated into some sort of assessment for the course. Naming, however, when deployed strategically, possesses different stakes that exceed the bounds the class and finds life in the real world.

Naming not only provides a concise heuristic framing for the course, it allows the class to explore the ways that a single term or phrase can be deployed, interpreted, exploited, and subverted across a number of historic instances by a variety of persons, parties, and movements. Naming, then, provides a thematic device that can be used to tie together seemingly disparate periods, people, and movements. It signals to the student that each life, idea, or movement named in the class has meaningful weight, warrants discovery, and seeks deeper disclosure. It gives 
voice to the passions and energies of a society or group. It represents real oppression, suffering, and resistance. Naming is never innocuous but represents an attempt to counter-signify a community in such a way as to disrupt and challenge the power structures working against it. Regardless of the content-focus that is undertaken, the need to teach race and white supremacy intersectionally in religious studies courses persists because the urgency \#BlackLivesMatter and other counter-significations has not abated. 
Bibliography

Accapadi, M. M. (2009). When a safe space becomes an oppressive space: Christmas in a cultural center. In W. J. Blumenfeld (Ed.), K. Y. Joshi (Ed.), and E. E. Fairchild (Ed.), Investigating christian privilege and religious oppression in the united states (pp. 113131), Rotterdam: Sense Publishers.

al-Ahari, M. A. (Ed.). (2006). Five classic muslim slave narratives. Chicago, IL: Magribine Press.

Baker, K. J. (2011). Gospel according to the klan: The KKK's appeal to protestant america, 1915-1930. Lawrence, KS: University Press of Kansas.

Burlein, A. (2002). Lift high the cross: Where white supremacy and the christian right converge. Durham, NC: Duke University Press.

Case, K. (Ed.). (2013). Deconstructing privilege: Teaching and learning as allies in the classroom. New York, NY: Routledge.

Curtis E. E. (2002) Islam in black america: Identity, liberation, and difference in africanamerican islamic thought. Albany, NY: State University of New York Press.

Dannin, R. (2002). Black pilgrimage to islam. New York, NY: Oxford University Press.

DiAngelo, R. (2011). White fragility. International Journal of Critical Pedagogy, 3(3), 54-70.

Fletcher J. H. (2017). The sin of white supremacy: Christianity, racism, \& religious diversity in america. Maryknoll, NY: Orbis Books.

hooks, b. (1994). Teaching to transgress: Education as the practice of freedom. New York, NY: Routledge.

Jennings, W. J. (2011). The christian imagination: Theology and the origins of race. New Haven, CT: Yale University Press. 
Johnson, J. R., González, M., Ray, C., Hager, J., Leon, D., Spalding, S., \& Brigham, T. (2012) Daring pedagogy: Dialoguing about intersectionality and social justice. In S. M. Pliner (Ed.) \& C. A. Banks (Ed.). Teaching, learning, and intersecting identities in higher education (pp. 179-199). New York, NY: Peter Lang Publishing.

Johnson, S. A. (2015). African american religions, 1500-2000. Cambridge: Cambridge University Press.

Lebron, C. J. (2017). The making of black lives matter: A brief history of an idea. New York, NY: Oxford University Press.

Long, C. H. (1986). Significations: Signs, symbols, and images in the interpretation of religion. Philadelphia, PA: Fortress Press.

McCloud, A. B. (1995). African american islam. New York, NY: Routledge.

Mills, C. W. (1997). The racial contract. Ithaca: Cornell University Press.

Mitchell, T. D. (2015). Identity and social action: The role of self-examination in systemic change. Diversity \& Democracy, 18(4), 15-17.

Mitchell, T. D. (2018). Citizen scholars' conceptions of social justice. In T.D. Mitchell (Ed.) \& K. M. Soria (Ed.). Educating for citizenship and social justice: Practices for community engagement at research universities (pp. 129-148). Cham, Switzerland: Palgrave Macmillian.

Mitchell, T. D., Richard, F. D., Battistoni, R. M., Rost-Banik, C., Netz, R., \& Zakoske, C. (2015). Reflective practice that persists: Connections between reflection in servicelearning programs and in current life. Michigan Journal of Community Service Learning, 21(2), 49-63.

Pliner, S. M., \& Banks, C. A. (Eds.). (2012). Teaching, learning, and intersecting identities in 
higher education. New York, NY: Peter Lang Publishing.

Said, N. (2000). The autobiography of nicholas said. P. Muhammad (Ed.). Cambridge, MA: Journal of Islam in America Press.

Said, O. b. (2011). A muslim american slave: The life of omar ibn said. A. Alryyes (Ed. \& Trans.). Madison, WI: University of Wisconsin Press

Schulman, G. (2012). From political theology to vernacular prophecy: Rethinking redemption. In V. W. Llyod (Ed.), Race and Political Theology (pp. 234-247). Stanford, CA: Stanford University Press.

Tatum, B. D. (1992). Talking about race, learning about racism: The application of racial identity development theory in the classroom. Harvard Educational Review, 62(1), 1-24.

Taylor, K.-Y. (2016). From \#Blacklivesmatter to black liberation. Chicago: Haymarket Books.

Turner, R. B. (2003). Islam in the african-american experience, second edition. Bloomington, IN: Indiana University Press.

Yancy, G., \& Davidson, M. (Eds.). (2014). Exploring race in predominantly white classrooms: Scholars of color reflect. New York, NY: Routledge.

Yancy, G. (2017). On race: 34 conversations in a time of crisis. New York, NY: Oxford University Press. 